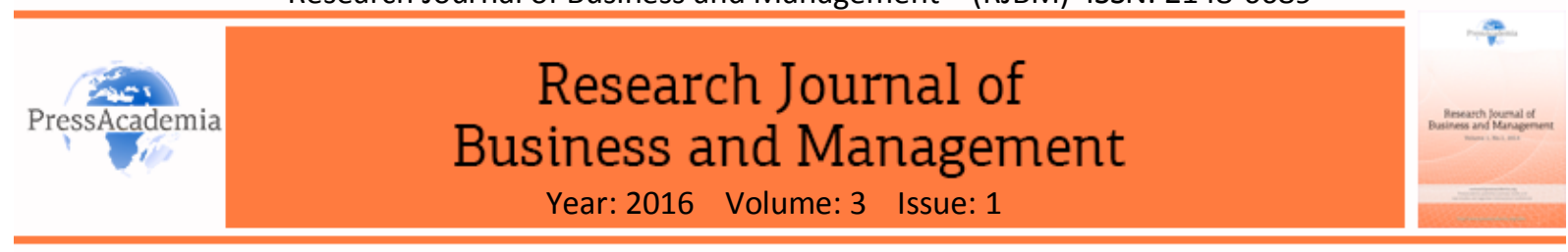

\title{
EFFECTS OF THE PERFORMANCE-BASED REMUNERATION SYSTEM: WHAT DO NURSES THINK?
}

\section{DOI: 10.17261/Pressacademia.2016116547}

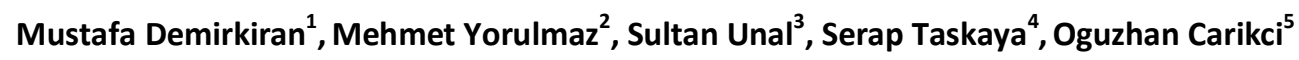 \\ ${ }^{1}$ Süleyman Demirel University. m-demirkiran@hotmail.com \\ ${ }^{2}$ Selçuk University. mtyorulmaz@hotmail.com \\ ${ }^{3}$ Konya Beyhekim State Hospital. sultan unal 1453@outlook.com \\ ${ }^{4}$ Aksaray University. seraptaskaya@yahoo.com \\ ${ }^{5}$ Mehmet Akif Ersoy University. o.carikci@hotmail.com
}

\begin{abstract}
Performance-based remuneration system has come into use widely in the affiliated institiutions of the Ministry of Health of the Republic of Turkey since 2004. In this system, all working personnel benefit from extra pay whereas only the activities performed and finalized by physicians are scored. The activities conducted by non-physician personnel including nurses are not scored. This study intends to determine nurses' views concerning the performance-based remuneration system and its effects. The questionnaire developed by researchers for this purpose was responded by 149 nurses working in a public hospital in the province of Konya (Turkey). According to the findings, the performance-based remuneration system increases the workload of nurses, forces nurses to fulfill the duties that are not included in their job description, makes physicians financially more privileged, has negative effects on the quality of patient care and the relationships between nurse-physician, nurse-patient, nurse-family and causes nurses to experience professional burnout syndrome. The majority of nurses $(80.5 \%)$ want the direct performance-based remuneration system that is applied to physicians to be also applied to nurses.
\end{abstract}

Keywords : Ministry of health, performance, remuneration system, nurses, hospitals JEL Classification : I18, I19, M21

\section{INTRODUCTION}

People employed in any organization differ from one another in terms of personal traits, educational status, knowledge and skills, belief-attitude and behavioral patterns and modus operandi. Owing to such differences, each employee demonstrate a different individual performance while doing his/her task. One of the most important issues encountered in a place of business is the failure to establish a just remuneration system based on different individual performance levels. For the majority of employees facing a such problem, the real issue is not receiving less wages for the work done but seeing those who spend less effort than themselves get similar or higher amounts of wages than themselves. When considered from this point of view, equal pay for equal work or performance-based remuneration system stands out among the alternatives (Erkan, 2011).

Performance based remuneration is defined as the "distribution of money or pecuniary benefits in accordance with the previously set performance objectives or measurable behavioral conditions" (Eichler, 2006). Performance based remuneration constitutes the fundamental part of the performance management which makes it compulsory to determine the wages or bonuses in accordance with the previously set criteria or objectives. This way, the individual or group based performances of the employees are measured, and the performance can be associated with the wages (Kestane, 2003).

In order for a performance based remuneration system to work in a workplace, it is necessary to identify the performance standards and criteria with which to measure the performance of the employees (Eraslan and Tozlu, 2011). Identification of performance standards and criteria is important for both the employees and the 
management. This way, the employees realize what is expected of them and have the opportunity to shape up their performance and skills in line with such expectations. While the management, on the other hand, has the opportunity to get to know the performance and skills of its employees, establish fair grounds for the decisions it may take regarding them and test out the results of the methods and technical changes it may choose to introduce. With this in mind, however, some issues need to be taken into account while identifying the performance standards and criteria. First of all, the criteria set should be fair and just, in that it should not favor one certain person or group over others. The criteria should focus on measuring what is important and avoiding unnecessary issues. It should be presented in such a way as to be perceived by each and every employee and it should not include processes that are beyond the employees' control. And lastly, the results should be made available to the employees and feedback should be provided (Kestane, 2003).

Practices of performance based remuneration system differ in public and private sectors. The frequently used methods in the private sector include profit distribution, commission, bonus and premium payments and share ownership. In the public sector, however, the most favored method is the distribution of benefits -created through point scoring systems- to the employees (Erkan, 2011). The public and private sectors also differ from each other in terms of their objectives while implementing their respective remuneration systems. While the main goal in designing a performance based remuneration system in private sector is to maximize profits, the main goal of the public sector is to meet the requirements of the citizens in the best possible way or to ensure the common good (Eraslan and Tozlu, 2011).

One of the public institutions that implements the performance based remuneration system in the most effective manner is the Ministry of Health. Having first introduced a pilot scheme in 10 hospitals in 2003, the Ministry of Health extended the performance based remuneration system to all medical institutions from 2004 onwards (Ministry of Health, 2006). The legal basis for the system is provided by the "Law on the Circulating Capital to be Allocated to the Medical Institutions and Rehabilitation Facilities Associated with the Ministry of Health" (Erkan, 2011). Individual and quantitative performance criteria were found to be effective in the system in 2004, which paved the way for the addition of corporate performance criteria in 2005, thus bringing a qualitative aspect into the system. One of the important elements of the system is the point-based assessment of the medical procedures conducted in the medical institutions by identifying their relative values. For the point based assessment, the physical and cognitive activities that are actually conducted by the physicians (e.g. treatment, surgery, interventional procedures etc.) are taken into account whereas the procedures that are actually conducted by other medical personnel (e.g. injections, laboratory procedures etc.) are not considered even if they are under the responsibility of physicians. The medical and administrative personnel whose services are not scored are rated in accordance with the average rating of the institution. In this system, clinician doctors'performance is directly measured while administrators, laboratory physicians and other medical personnel's performance is meausured indirectly and the amounts thus calculated are reflected in the wages as contributions other than the actual wage (Ministry of Health, 2006).

Performance based remuneration system is an efficient method in bringing about a quantitative increase in health services and setting in motion an otherwise cumbersome structure (Ministry of Health, 2006). However, the system has some significant drawbacks such as the increase in health costs and competition, favoring quantitative increase over qualitative increase, and inability to rate every single procedure (Kızlkan et al., 2012). Moreover, in this system, the activities performed by non-physician personnel cannot be directly rated. Therefore the system may have some negative consequences for the said personnel. This study has been conducted for the purpose of identifying the views of the nurses regarding the performance based remuneration system and its effects. This research performed for this purpose consists of four parts. The second part followed by this part includes the details regarding the method such as location where the research was conducted, the population of the research, the number of respondents and the data collection tool. The analysis findings are presented in the third part of the research. In the last section, findings are assessed and suggestions are presented. This study is important because it includes non-physician personnel's views unlike the previous studies on this topic. 


\section{DATA AND METHODOLOGY}

This study has been conducted in a public hospital located in Konya, Turkey. The hospital in question employs 290 nurses. Efforts have been made to contact all the nurses without limitation. In the end, 154 nurses have agreed to participate in the study. 5 of the questionnaires were cancelled as they were found to have contained significantly insufficient data, and thus 149 questionnaires were taken into evaluation.

A survey method was employed in the collection of the study related data. The survey used was originally developed by the researchers and it consists of two parts. The first part contains questions regarding the personal and professional characteristics of the nurses. The second part of the survey contains 11 questions aiming to identify the views of the nurses regarding the performance based remuneration system and its effects which included 3 choices for each question indicating "yes", "partially" and "no".

\section{FINDINGS}

149 nurses have participated in the present study aiming to determine the nurses' views on the performance based remuneration system and its effects, and the distribution of the participants based on their personal and professional characteristics is shown in the Table 1 below.

Table 1: Distribution of Participants Based on their Personal and Professional Characteristcs

\begin{tabular}{|c|c|c|}
\hline Variables & Number & Percentage \\
\hline \multicolumn{3}{|l|}{ Gender } \\
\hline Female & 105 & 70,5 \\
\hline Male & 44 & 29,5 \\
\hline Total & 149 & 100,0 \\
\hline \multicolumn{3}{|l|}{ Age (Years) } \\
\hline-25 & 40 & 26,8 \\
\hline $26-35$ & 64 & 43,0 \\
\hline $36-45$ & 45 & 30,2 \\
\hline Total & 149 & 100,0 \\
\hline \multicolumn{3}{|l|}{ Marital Status } \\
\hline Married & 97 & 65,1 \\
\hline Not Married & 52 & 34,9 \\
\hline Total & 149 & 100,0 \\
\hline \multicolumn{3}{|l|}{ Educational Status } \\
\hline High School & 22 & 14,8 \\
\hline Associate Degree & 60 & 40,3 \\
\hline Undergraduate Degree & 62 & 41,6 \\
\hline Graduate Degree & 5 & 3,3 \\
\hline Total & 149 & 100,0 \\
\hline \multicolumn{3}{|l|}{ Total Period of Service (Years) } \\
\hline-3 & 27 & 18,1 \\
\hline $4-6$ & 47 & 31,5 \\
\hline $7-9$ & 34 & 22,8 \\
\hline $10+$ & 41 & 27,5 \\
\hline Total & 149 & 100,0 \\
\hline \multicolumn{3}{|c|}{ Period of Service at the Institution (Years) } \\
\hline-3 & 67 & 44,9 \\
\hline $4-6$ & 64 & 43,0 \\
\hline $7-9$ & 13 & 8,7 \\
\hline $10+$ & 5 & 3,4 \\
\hline Total & 149 & 100,0 \\
\hline
\end{tabular}




\begin{tabular}{|l|c|c|}
\hline Department & 14 & 9,4 \\
\hline Emergency Department & 35 & 23,5 \\
\hline Intensive Care Units & 11 & 7,4 \\
\hline Operating Theater & 80 & 53,7 \\
\hline Inpatient Services & 9 & 6,0 \\
\hline Other Departments & 149 & 100,0 \\
\hline Total & & \\
\hline
\end{tabular}

Of the participants, 105 were women (70.5\%) and 44 were men (29.5\%). While 64 participants (43\%) were aged between 26 and 35 years, 45 of them (30.2\%) were aged between 36 and 45 years, and 40 participants (26.8\%) were below 26 years of age. A majority of the participants (65.1\%) were married. When reviewed in terms of their educational status, it was seen that 62 of them (41.6\%) had an undergraduate degree, 60 (40.3\%) had an associate degree, 22 (14.8\%) had a high school diploma, while 5 of them (3.3\%) had a graduate degree. 47 of the participants (31.5\%) had worked in the hospital for 4 to 6 years. When reviewed in terms of their employment history with the hospital, it was seen that 131 of the participants (88\%) had been working in the same institution for 6 years or less. Of the said personnel, 80 (53.7\%) were employed in the inpatient services, $35(23.5 \%)$ in the intensive care units, 14 (9.4\%) in the emergency department, $11(7.4 \%)$ in the operating theater, and $9(6 \%)$ in the other departments of the hospital.

Figure 1: Nurses' Awareness of Performance Based Remuneration System (\%)

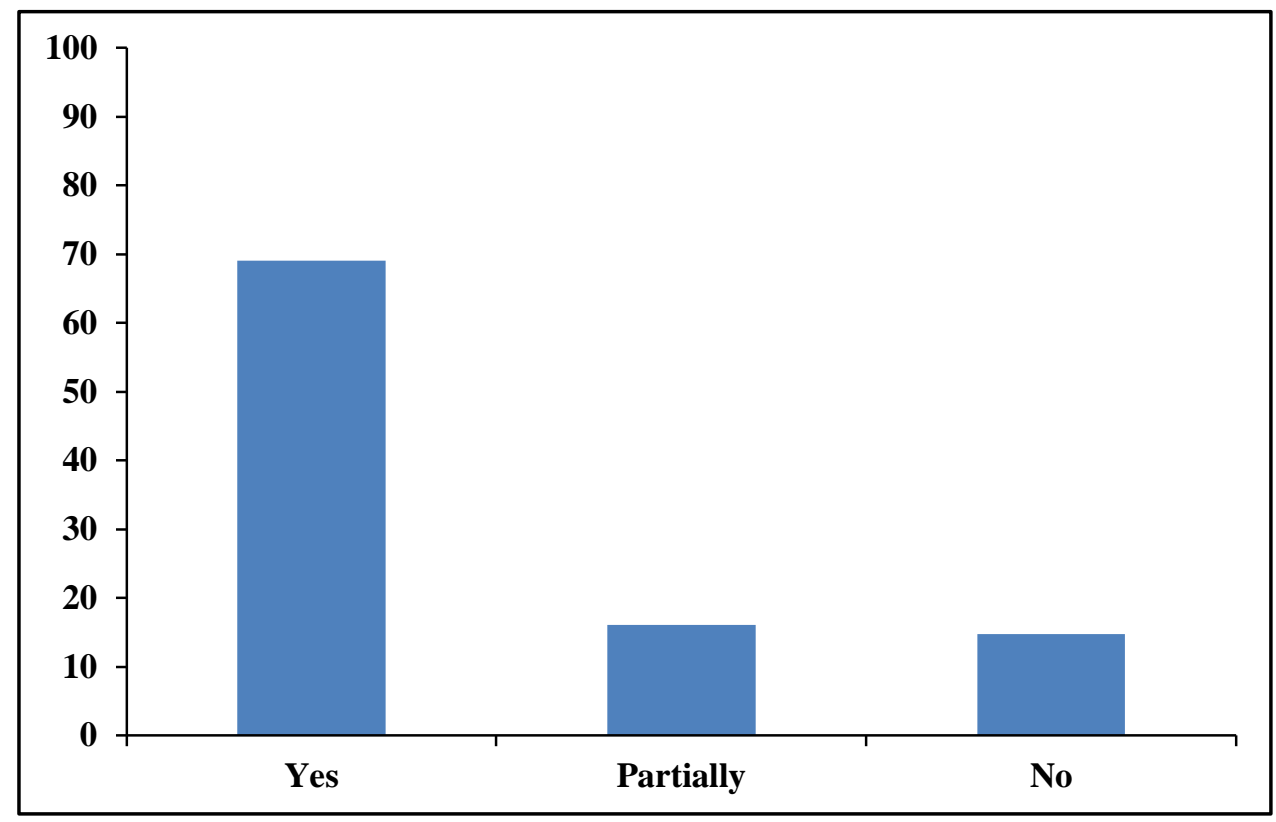

Figure 1 shows the nurses' awareness of performance based remuneration system. According to the figures above, a majority of the nurses (69.1\%) believe that they are sufficiently informed about the performance based remuneration system. The ratio of those who think that they are partially informed about the said system is $16.1 \%$, while the ratio of those who think they are insufficiently informed about the system is $14.8 \%$. 
Table 2: Participants' Views on the Effects of Performance Based Remuneration System

\begin{tabular}{|c|c|c|}
\hline Items & $\mathbf{n}$ & $\%$ \\
\hline \multicolumn{3}{|c|}{ Does performance based remuneration system increase the nurses' workload? } \\
\hline Yes & 135 & 90,6 \\
\hline Partially & 8 & 5,4 \\
\hline No & 6 & 4,0 \\
\hline Total & 149 & 100,0 \\
\hline \multicolumn{3}{|c|}{$\begin{array}{l}\text { Does performance based remuneration system cause nurses to perform tasks } \\
\text { that are not included in their job description? }\end{array}$} \\
\hline Yes & 121 & 81,2 \\
\hline Partially & 19 & 12,8 \\
\hline No & 9 & 6,0 \\
\hline Total & 149 & 100,0 \\
\hline \multicolumn{3}{|c|}{ Does performance based remuneration system make physician more privileged? } \\
\hline Yes & 125 & 83,9 \\
\hline Partially & 16 & 10,7 \\
\hline No & 8 & 5,4 \\
\hline Total & 149 & 100,0 \\
\hline \multicolumn{3}{|c|}{$\begin{array}{l}\text { Does performance based remuneration system result in an inefficient use of the } \\
\text { hospital's resources? }\end{array}$} \\
\hline Yes & 68 & 45,6 \\
\hline Partially & 64 & 43,0 \\
\hline No & 17 & 11,4 \\
\hline Total & 149 & 100,0 \\
\hline \multicolumn{3}{|c|}{ Does performance based remuneration system reduce the patient care quality? } \\
\hline Yes & 101 & 67,8 \\
\hline Partially & 35 & 23,5 \\
\hline No & 13 & 8,7 \\
\hline Total & 149 & 100,0 \\
\hline \multicolumn{3}{|c|}{$\begin{array}{l}\text { Does performance based remuneration system affect the relationship between the } \\
\text { physician and nurse in a negative way in terms of labor peace? }\end{array}$} \\
\hline Yes & 104 & 69,8 \\
\hline Partially & 41 & 27,5 \\
\hline No & 4 & 2,7 \\
\hline Total & 149 & 100,0 \\
\hline \multicolumn{3}{|c|}{$\begin{array}{l}\text { Does performance based remuneration system affect the relationship between the } \\
\text { nurse and patient in a negative way? }\end{array}$} \\
\hline Yes & 105 & 70,5 \\
\hline Partially & 32 & 21,5 \\
\hline No & 12 & 8,0 \\
\hline Total & 149 & 100,0 \\
\hline
\end{tabular}




\begin{tabular}{|c|c|c|}
\hline \multicolumn{3}{|c|}{$\begin{array}{l}\text { Does performance based remuneration system affect the nurses' domestic life in a } \\
\text { negative way? }\end{array}$} \\
\hline Yes & 97 & 65,1 \\
\hline Partially & 30 & 20,1 \\
\hline No & 22 & 14,8 \\
\hline Total & 149 & 100,0 \\
\hline \multicolumn{3}{|c|}{$\begin{array}{l}\text { Does performance based remuneration system trigger a professional burnout } \\
\text { syndrome in nurses? }\end{array}$} \\
\hline Yes & 111 & 74,5 \\
\hline Partially & 24 & 16,1 \\
\hline No & 14 & 9,4 \\
\hline Total & 149 & 100,0 \\
\hline
\end{tabular}

The participants' views on the effects of the performance based remuneration system are listed in the Table 2 . $90.6 \%$ of the nurses stated that the performance based remuneration system increased their workload. Again a great majority of the participants (81.2\%) said that the performance based remuneration system cause nurses to perform tasks that are not officially included in their job descriptions. In a similar manner, a great majority of the participants (83.9\%) believed that the said system made physicians financially more privileged.

According to the findings, the performance based remuneration system was influential on the overall quality and efficiency. In this respect, $45.6 \%$ of those participating in the survey stated that it resulted in an inefficient use of the hospital's resources, while $67.8 \%$ of them stated that it reduced the patient care quality.

Moreover, according to the Table 2, the performance based remuneration system had also negative effects on the relationships between nurses and physicians, between physicians and patients, and between nurses and their families. The ratio of those who believed that the performance based remuneration system affected the relationship between the nurses and physicians in a negative way was $69.8 \%$; while the ratio of those who thought it affected the relationship between the nurses and patients in a negative way was $70.5 \%$; and the ratio of those who thought that it affected the relationship between the nurses and their family in a negative way was $65.1 \%$. $74.5 \%$ of the nurses stated that they experienced professional burnout syndrome due to the aforementioned and other related negative consequences of the performance based remuneration system. 


\section{Figure 2: Nurses'Willingness to Subject Themselves Directly to the Performance Based Remuneration System}

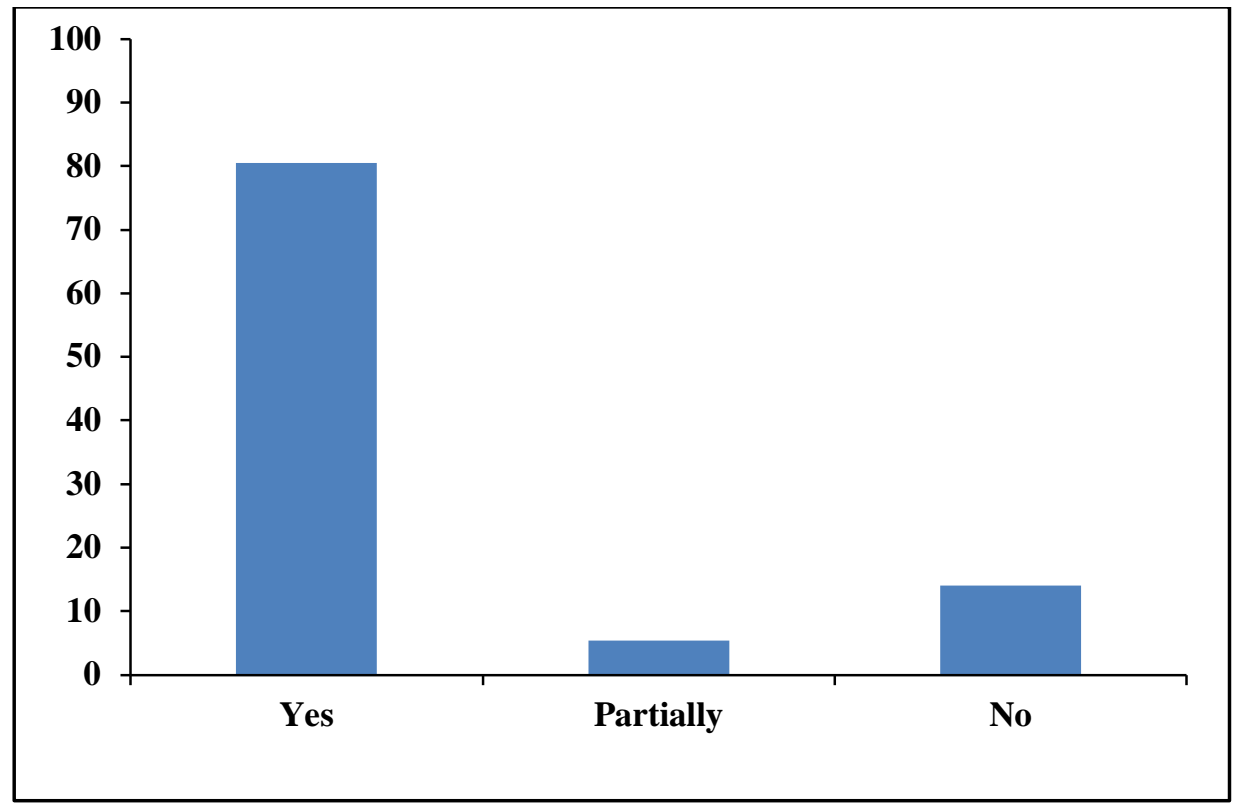

Moreover the nurses were asked the following question "would you like the performance based remuneration system being applied to the physicians to be directly applied to you?". While $80.5 \%$ of the nurses replied to this question affirmatively, only $14.1 \%$ of them said "no" (Figure 2 ).

\section{CONCLUSION}

Performance-based remuneration (extra pay) system has been implemented in the Ministry of Health of the Republic of Turkey since 2004. The purpose of the system is to integrate the corporate objectives with that of the individual ones and shape the value created by individuals in line with these common purposes and targets. (Ministry of Health, 2006). However, when the actual practice is observed, it is seen that only the activities of the physicians are translated into performance scores, while the tasks accomplished by the other personnel are not subject to the rating. From this point of view, it is important to identify the non-physician health personnel's views on the performance based remuneration system. Thus this study has been conducted for the purpose of identifying the views of the nurses regarding the performance based remuneration system and its effects.

According to the findings of this study, the nurses are sufficiently aware of the performance based remuneration system. The fact that the extra pay received by all the personnel employed at the hospital is more or less influenced by this system can be regarded as the proof of sufficient awareness of the system.

A significant number of nurses participating in the study stated that the performance based remuneration system increased their workload and caused them to perform tasks that are not officially included in their job description. This could be explained by the increase in the bureaucratic procedures brought about by the system and through unnecessary analyses, inspections, procedural interventions etc. or by the reflection of the increase in the physicians' performance on the nurses in a positive way. The study conducted by the Turkish Physicians Association (2009) with 1469 physicians employed in the 1st, 2nd and 3rd echelons found that the performance based remuneration system served to increase various procedures carried out in health institutes. According to Sülkü (2011), performance based extra pay system helped increase the efficiency of the health personnel and the number of healthcare services provided. 
Another finding of this study suggests that the system makes physicians financially more privileged. Physicians are the group of employees that most benefits from the performance based remuneration system. The financial difference between the physicians and other personnel may go as high as tenfold in this respect. Moreover, even if the non-physician health personnel go out of their way to get things done, the extra pay they receive will not be any different. The aforementioned reasons can be regarded as the grounds on which the nurses claim that the physicians are made financially more privileged by the system. According to the literature, various studies conducted on the subject (Bolat, 2012; Küçük et. al, 2012; Fettah and Şahin, 2009) put forward the view that the performance based remuneration system implemented by the Ministry of Health is not fair.

According to the findings of this study, the performance based remuneration system is also influential on the overall quality and efficiency. In this respect, $45.6 \%$ of the nurses participating in the survey stated that it resulted in an inefficient use of the hospital's resources, while $67.8 \%$ of them stated that it reduced the patient care quality. Such views held by the nurses can be explained by the physicians' discretion to minimize the amount of time they spend with each patient so that they can tend to more patients and carry out some procedures that others may find unnecessary. The other studies conducted on the subject (Bolat, 2012; Küçük et. al, 2012) also found that the system did not actually improve the patient care quality. Moreover, the findings of the study regarding efficiency were also contradictory (Sülkü, 2011; Bolat, 2012).

According to the majority of the nurses, the performance based remuneration system had also negative effects on the relationships between nurses and physicians, between physicians and patients, and between nurses and their families. As mentioned above, the performance based remuneration system increases the nurses' workload and causes them to perform tasks that are not officially included in their job description. Moreover, the huge difference between the extra pay received by the physicians and nurses and the lack of difference between the hard working and not so hard working nurses in terms of extra pay may cause tensions in the relationships. This will inevitably be reflected on the patients and family members. As a matter of fact, $74.5 \%$ of the nurses stated that they experienced professional burnout syndrome because of this system.

In the light of the findings of this study, the following suggestions could be made;

- As in the case of the physicians, the performance of the other health personnel should also be directly measured and rated. To do this, the performance criteria and standards for non-physician health personnel should be created. This way, the extra pay allocated to the hard working and not so hard working nurses will be fair and just. As a matter of fact, according to the findings of this study, a large majority of the nurses $(80.5 \%)$ wish to have the same kind of direct performance based remuneration system that is currently being applied to the physicians.

- The huge gap between the physicians and other health personnel in terms of extra pay should be minimized. This way, the communication between the physicians and nurses can be improved and the level burnout syndrome experienced by the nurses may be reduced.

- Measures should be taken to avoid increasing the nurses' workload, such as increasing the number of nurses and not assigning them the tasks that are outside their job description.

- Measures should be taken to avoid wasting the health institutes' resources and arrangements should be put in place to increase the amount of time physicians spare for their patients. 


\section{REFERENCES}

Bolat, G. (2012). Performansa Dayalı Ücret Sisteminin İşgören Motivasyonuna Etkisi, Atılım Üniversitesi Sosyal Bilimler Enstitüsü Yüksek Lisans Tezi, Ankara.

Eichler, R. (2006). Can “Pay for Performance" Increase Utilization by the Poor and Improve the Quality of Health Services?, Discussion Paper for the First Meeting of the Working Group on Performance-Based Incentives Center for Global Development.

Eraslan, M. T. and Tozlu, A. (2011). “Kamu Yönetiminde Performansa Dayalı Ücret Sistemi”, Sayıştay Dergisi, 81, p. 33-61.

Erkan, A. (2011). “Performansa Dayalı Ödeme: Sağlık Bakanlığı Uygulaması”, Maliye Dergisi, 160, p. 423-437.

Fettah, K. and Şahin, B. (2009), "Birinci Basamak Sağlık Kuruluşlarında Çalışan Personelin Performansa Dayalı Döner Sermaye Ek Ödeme Uygulamasına İlişkin Değerlendirmeleri”, Hacettepe Sağlık İdaresi Dergisi, 12(2), p. 177-201.

Kestane, D. (2003). “Performansa Dayalı Ücret Sistemi ve Kamu Kesiminde Uygulanabilirliği”, Maliye Dergisi, 142, p. 126-144.

Kızılkan, A.Ç., Öztürk, G. and Yıldıran, N. (2012). "Sağlıkta Dönüşümde Performans Uygulamaları”, TAF Preventive Medicine Bulletin, 11(6), p. 757-766.

Küçük, A., Gökçınar, D., Aksoy, E., Albayrak, D., Erdem, D., Akan, B. and Göğüş, N. (2012). “Performansa Göre Ek Ücret Ödenmesinin Anestezi Uygulamalarına Etkileri", Turkish Journal of Anaesthesiology and Reanimation, 40(5), p. 262-268.

Ministry of Health. (2006). Sağııta Performans Yönetimi Performansa Dayalı Ek Ödeme Sistemi, Sağlık Bakanlığı Yayınları, Ankara.

Sülkü, S.N. (2011). "Performansa Dayalı Ek Ödeme Sisteminin Kamu Hastanelerinin Verimliliği Üzerine Etkileri”, Maliye Dergisi, 160, p. 242268.

Turkish Physicians Association. (2009). Hekimlerin Değerlendirmesi ile Performansa Dayalı Ödeme, Türk Tabipleri Birliği Yayınları, Ankara. 